\title{
НЕАДАПТИВІ КОПІНГ-СТРАТЕГІЇ ПОВЕДІНКИ ЯК ПРЕДИКТОРИ ПРОКРАСТИНАЦЇ̈ ДЕРЖАВНИХ СЛУЖБОВЦІВ
}

Котляр Л.I., доцент, докторант Національна академія державного управління при Президентові України, м. Київ, Україна.

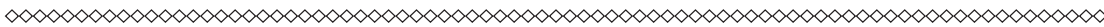

Стаття присвячена дослідженню неадаптивних копінгстратегій поведінки як предикторів прокрастинації державних службовиів, виявленню основних тенденцій. Державний службовець, як суб 'єкт управління, при виконанні своїх професійних функцій, постійно працює в умовах вибору прийняття рішення для подолання негативного впливу складних ситуачій, таких, що за своїми параметрами перевищують його компетентності та ресурсний потенціал. Професіоналізм державних службовиів виявлясться в здатності переборювати труднощі при виникненні великої кількості ситуацій, щзо пов'язані з прийняттям рішень, які не повинні відкладатися на потім.

За умови не адаптивної копінг-стратегії поведінки, державний службовець використовує тактику прокрастинації та сфера пошуку рішення з подолання неприємної ситуації обмежується діями, які зменшують його контакти з цим положенням, а дї з переборення неприємного стану активно скасовуються державним службовием, як несприятливі.

Неадаптивні копінг-стратегіі поведінки у подоланні складних ситуацій при виконанні справ і прийняття рімень $\epsilon$ предикторами прокрастинації державних службовців в управлінської діяльності. $У$ результаті аналізу наукових джерел визначено сутність та основні ознаки неадаптивних копінг-стратегій поведінки, які $е$ засобами прогнозування прокрастинації державних службовщів в управлінській 
діяльності. Зокрема унауковій статті проаналізовані актуальні наукові підходи до визначення термінів. Визначені найістотніші аспекти вищевказаних явищ показали, щуо прокрастинація $\epsilon$ негативне явище, яке перешкоджає суспільному розвитку $i$ розуміється як постійне відкладання актуальних $і$ важливих справ та прийняття рішень, щзо завжди повторюються всупереч усвідомленню державними службовцями негативних наслідків та неготовністю взяти на себе відповідальність.

Репрезентоване авторське ставлення щзодо визначення неадаптивних копінг-стратегіїи поведінки у подоланні складних ситуаційпривиконаннісправ іприйняття рішень, якієпредикторами прокрастинації державних службовців в управлінській діяльності. Неадаптивними копінг-стратегіями поведінки $\epsilon$ : фокусування на емоціях і їх вирішенні; заперечення; ментальне та поведінкове відчуження; уникнення; ігнорування; примирення; дисимуляція.

Ключові слова: державний службовецьь, прокрастинація, політична прокрастинація, предиктор, копінг-стратегї̈ поведінки, неадаптивні копінг-стратегії поведінки.

Постановка проблеми у загальному вигляді. Особистість, яка обирає своєю професією державну службу, має усвідомлювати велику суспільну довіру громадян, які наділяють іiі посадовим авторитетом, розуміти напружений та важкий ритм життя, значення необхідності здійснювати управлінську діяльність в умовах подолання труднощів при виникненні великої кількості складних ситуацій, що пов'язані 3 прийняттям рішень без прокрастинації. На сьогоднішній день у взаємодії урядовців 3 населенням та громадськістю спостерігається досить низький рівень довіри спільноти до різних гілок влади, 3 причини відкладання державними службовцями актуальних і важливих справ та невчасного прийняття управлінських рішень. Неадаптивні копінг-стратегії поведінки в управлінській діяльності можуть бути предикторами прокрастинації державних службовців. 
Аналіз останніх досліджень і публікацій. Як показує аналіз наукових праць зацікавленість проблемою прокрастинації на сьогодні дуже велика. Сучасні наукові дослідження приходять до висновку, що прокрастинація - це схильність людини до зволікання в ухваленні рішення, відкладання виконання різних справ «на потім». Питаннями пояснення змісту механізмів прокрастинації займалися С. Базика, Н. Боровська, Т. Вайда, Я. Варваричева, В. Воробйова, М. Дворник, В. Ковилін, М. Кузнєцов, Т. Мотрук, В. Мичко та ін. Аналіз наукової літератури 3 проблеми копінгповедінки показав, що вона $є$ однією 3 актуальних при розгляді адаптивних чи неадаптивних можливостей особистості. Окремі питання поняття «копінг-поведінка» досліджували такі вітчизняні науковці як Р. Грановська, А. Лібін, А. Лібіна, С. Нартова-Бочавер та інші. В Україні проблеми копінг-поведінки у професійній діяльності вивчали М. Дідух, В. Доценко, М. Кожанова, Л. Колесніченко, А. Колчигіна, А. Левенець, О. Самара, 3. Сивогракова, О. Склень, А. Якимчук та інші. Проблема копінг-поведінки у професійній діяльності фахівців державної служби досліджували такі вчені як Н. Дубинко, О. Ічанська.

Найбільше розповсюдження отримали роботи, дослідження та підходи зарубіжних фахівців, які розглядали різні аспекти копінгповедінки Р. Лазарус, Р. Моуз, С. Фолкман, Н. Хаан та інші.

\section{Формулювання цілей статті (постановка завдання).} Проаналізувати поняття прокрастинації та копінг-стратегій поведінки в контексті різних теоретичних підходів, визначити неадаптивні копінг-стратегії поведінки як предикторів прокрастинації в професійній діяльності державних службовців.

Виклад основного матеріалу дослідження. Професіоналізм особистості державного службовця виявляється у сформованості індивідуально-особистісної та професійної компетентності у поєднанні зі спеціальними здібностями нарощувати потенціал підготовленості виконання управлінської діяльності, саморозвитку, самоосвіти та виховання як власних особистісних та професійних якостей, так i у підпорядкованих працівників. Використання неадаптивних копінг-стратегій поведінки в управлінській діяльності 
$\epsilon$ предикторами прокрастинації фахівців, а постійне відкладання актуальних i важливих справ та прийняття рішень на потім, демонструє непрофесіоналізм державних службовців i знижує рівень довіри громадськості до державного управління.

Складна проблематика відкладання справ є важливим запитом, яке активно досліджується дослідниками різних країн світу, завдяки великому зростанню кількості людей, які прокрастинують, і низкою негативних результатів цього процесу: несприятливий вплив на кар'єрне зростання, професійну успішність, на розвиток людини, іiі працездатність, продуктивність в роботі.

Предиктор (від англ. predictor «провісник») - прогностичний показник; засіб прогнозування.

Прокрастинація (від латів. pro - замість, попереду і crastinus завтрашній) означає схильність до постійного відкладання «на потім», «на завтра», на майбутнє складні або неприємні справи та рішення. Прокрастинатори це люди, які схильні відтерміновувати виконання завдань, перекладати відповідальність на інших, виконувати певну роботу непослідовно, без плану.

Актуальними у контексті аналізу літератури $є$ результати дослідження Ю. Шайгородського, який розглядає поняття «політичної прокрастинації» та розуміє його як відкладання (уникання) прийняття й реалізації важливих політичних рішень. Це «явище найчастіше зумовлюється неготовністю суб'єкта, котрий має прийняти таке рішення, взяти на себе відповідальність за його наслідки, що може зумовлюватися сумнівами щодо успішності реалізації, або ж усвідомленням нездатності подолати конфлікт, котрий виникне внаслідок прийняття рішення» [16, с.87]. Автор розглядає зміст цього явища в наявності особливостей, пов'язаних 3 процесом прийняття владного рішення, так і з мотивацією суб'єкта, котрий приймає рішення. Як процес цей феномен розкривається в когнітивних поняттях: рефлексія, завдання, досвід, цілепокладання та ін. Політична прокрастинація, яка зумовлена мотивацією, тобто випливає із самоідентифікації суб'єкта прийняття політичного рішення та його інтересів, описується аксіологічними й етичними поняттями: ідентичність, світогляд, цінності, відповідальність, 
інтерес. Наслідком політичної прокрастинації є суспільно-політична стагнація і делегітимація суб'єкта [16].

Результати досліджень Ю. Шайгородського, приводять дослідника до розуміння стратегії суспільного розвитку як «світоглядно обумовленої сукупності поглядів, оцінок та принципів, які визначають загальне бачення шляхів розвитку; достатньо абстрактний, довгостроковий, максимально загальний, послідовний, конструктивний, раціональний, підкріплений ідеологією, стійкий до невизначеності умов середовища план досягнення успіху. Реалізація такого плану передбачає забезпечення перетворення абстрактного у конкретне через деталізацію, пошук і апробацію засобів, постійний моніторинг, аналіз внутрішніх і зовнішніх факторів впливу на зміст, його коригування» $[17$, с.28].

Автор визначає три сутнісні ознаки стратегії суспільного розвитку: перша стратегія - найзагальніша світоглядна раціональна картина (уявлення) майбутнього та загальний вектор його досягнення; друга стратегія - своєрідна матриця, що містить сукупність віри, переконань, цінностей і водночас, - засобів й інструментів досягнення мети; третя стратегія - легітимований загальновизнаний i загальноприйнятний зразок («нормативний» шаблон) для вирішення поточних завдань, їх відповідності стратегічній меті [17].

На думку В. Ковиліна, прокрастинатор це людина, яка має схильність до відкладання в ухваленні рішення, відкладання виконання різних справ “на потім”. Дослідник розглядає зміст даного феномену в наявності намірів відкладати виконання необхідних справ “на потім”, як поведінковий патерн, при якому відбувається усвідомлене відкладання виконання провідної для людини в даний період часу діяльності, заповнюючи при цьому час позбавленими плідного сенсу діями [9].

P. Steel розробив теорію часової мотивації, яка була прагненням інтегрувати наукові погляди на причини прокрастинації. Автор пояснює це явище як добровільне відкладання індивідом запланованих справ, не дивлячись на очікувані негативні наслідки із-за затримки та як порушення регуляції діяльності (selfregulatory 
failure), за якого людина має схильність відкладати на потім складні чи неприємні для себе справи [24].

Відокремимо підходи щодо феномену прокрастинації, які пов'язані з емоційними реакціями особистості на заплановані або необхідні справи.

Привертають увагу роздуми дослідників Є. Ільїна і В. Ковиліна, які вважають прокрастинацію вираженням різного виду емоційної реакції $[8,9]$.

На основі проаналізованих дефініцій прокрастинації, вважаємо, що неадаптивні копінг-стратегії поведінки державних службовців $€$ предикторами прокрастинації в управлінській діяльності.

Розглянемо питання, щодо визначення поняття «копінгстратегії» поведінки у діяльності державних службовців. Поняття копінг розуміють як постійно змінювальні когнітивні, емоційні та поведінкові спроби впоратися із специфічними зовнішніми i внутрішніми вимогами, які оцінюються як напруга або перевищують можливість людини 3 ними впоратися [21, с.24]. Питання копінга особистості в важких життєвих ситуаціях виникла в психології у другій половині ХХ ст. Засновником терміну був А. Маслоу. Тлумачення поняття копінг (від англ. соре «долати»). Насамперед поняття копінг-поведінки застосовувалося в психології стресу і було з'ясовано як сума когнітивних і поведінкових зусиль, що витрачаються людиною для ослаблення впливу стресу. Слід констатувати, що поняття копінг охоплює широкий діапазон людської активності - від несвідомих психологічних захистів до цілеспрямованого подолання кризових ситуацій. Психологічна сутність копінга полягає в тому, щоб адаптувати людину до вимог ситуації.

Необхідно відзначити, що функціонування копінг-процесів передбачає включення когнітивних, моральних, соціальних i мотиваційних структур особистості в процесі подолання проблеми. У разі нездатності особистості адекватно подолати проблему включаються захисні механізми, що сприяють пасивної адаптації. Такі механізми визначаються як ригідні, дезадаптивні способи подолання проблеми, що перешкоджають адекватної 
орієнтації індивіда в реальній ситуації. Інакше кажучи, копінг i захист функціонують на підставі однакових его-процесах, але $\epsilon$ різноспрямованими механізмами у подоланні проблем [22, c.25]. Р. Лазарус вважав «психологічний захист пасивною копінгповедінкою».

Автор відокремив «захисні механізми і механізми подолання за наступними характеристиками: часової та інструментальної спрямованості, функціонально-цільової значущості і модальності регуляції. Часова направленість захисту означає вирішення важливої ситуації «тут і тепер», яка не пов'язана із майбутніми можливостями.

Отже відносно даної властивості захист -це «швидка допомога», що забезпечує психологічне виживання. Інструментальна спрямованість захисту означає його егоцентричну адресацію на власне психічне здоров'я і успіх, тоді як подолання - це соціально прийнятні засоби адаптивної поведінки із врахуванням середовища. Сутність функціональної поведінки подолання є у відродженні порушених відносин між оточенням та особистістю (механізм подолання), а захисні механізми спрямовані на збалансованість особистісних психічних станів» [21, с.37].

У контексті досліджуваної проблеми зазначимо, що вітчизняні науковці вважають, копінг-поведінку як стратегію дій особистості, спрямовану на усунення ситуації психологічної загрози. Стратегії поведінки, що включають в себе психологічний захист та співволодіння, є різними варіантами процесу адаптації і подібно внутрішньої картині життєвого шляху поділяються на соматично, особистісно та соціально орієнтовані, в залежності від переважної участі в адаптаційному процесі того чи іншого рівня життєдіяльності [14,c.245]. Цілісність захисних механізмів і копінг-поведінки визначена А. Лібіною. Авторка об'єднала в поняття «інтелект опанування всі можливості індивідуальної адаптації людини до важких повсякденних обставин, складність яких визначається не об'єктивними властивостями, а суб'єктивним сприйняттям» [13]. У зв’язку з цим А. Лібіна вважає, що « подолання стресу та захисні механізми закладають єдині стратегії адаптивної поведінки 
та аналізуються в параметрах трьох модальностей: когнітивної, емоційної та поведінкової. В якості системо утворюючого фактору в структурі «людина - складна життєва ситуація» виступає результат» [13].

Вибір людиною індивідуальних копінг-стратегій чи захисних стратегій залежить від інтенсивності взаємодії особистості із зовнішнім та внутрішнім світом. При цьому, погоджуємось 3 думкою А. Лібіної, що «захисні стратегії $є$ неефективними (з точки зору результату), неоптимальними (з точки зору внутрішніх витрат) і неконструктивними (з точки зору доцільності) засобами взаємодії людини із повсякденними ситуаціями. Стратегія це вектор когнітивних, емоційних і поведінкових зусиль людини, спрямованих у випадку подолання на вирішення життєвих обставин і відхилення від вирішення актуального ускладнення у випадку захисту» [13, с.32].

Актуальними у контексті аналізу літератури $є$ проблема негативного впливу психотравмуючих ситуацій на формування та розвиток порушень психічного здоров'я людини. Згідно концепції неврозогенеза В. Менделевича, виникнення неврозу розуміється «як результат нездатності особистості передбачати хід подій і власну поведінку під впливом фруструючих ситуацій, що обумовлено антиципаційною неспроможністю» [10]. Коли людина потрапляє у складні обставини, вона не завжди може використати всі свої можливості для подолання ситуації. У зв’язку 3 цим І. Абітов стверджує, «і навіть якщо у людини система психологічної компенсації функціонувала нормально, то в умовах розбіжності прогнозу і при крайній виразності емоційних переживань (образи, розчарування, здивування), пов'язаних 3 цією прогностичною помилкою, людина може не використовувати потенційні можливості до опанування ситуації, і у неї розвивається невроз» [1]. Важливо також звернути увагу на особливе значення особистісних якостей людини та iï здатності до передбачення виникнення складних обставин.

Копінг-поведінка реалізується за допомогою копінг-стратегій. Виділяють «наступні групи копінг-поведінки: вирішення проблем; пошук соціальної підтримки; уникнення» [4]. На думку М. Василенко, до копінг-стратегії «вирішення проблем» входять: 
«активний копінг - активні дії, які спрямовані на усунення джерела стресу; планування - планування своїх дій у конкретній стресовій ситуації; пошук активної соціальної підтримки - пошук поради серед соціального оточення; позитивне тлумачення та зростання - оцінка проблемної ситуації з позитивного погляду на неї; прийняття визнання реальності ситуації» [4]. Що стосується стратегії «пошуку соціальної підтримки», то «це активна поведінкова стратегія, коли людина для ефективного вирішення проблеми звертається за допомогою і підтримкою до оточуючих: родини, друзів, значущих інших. Копінг-стратегія «уникнення» - це поведінкова стратегія, коли людина намагається уникнути контакту 3 навколишньою дійсністю, відмовляється від вирішення проблем» [18].

Отже, під неадаптивними копінг-стратегіями поведінки ми розуміємо несвідомі психологічні захисти особистості, що сприяють пасивної адаптації та $є$ предикторами прокрастинації державних службовців в управлінської діяльності. Захисні механізми визначаються як ригідні, неадаптивні способи подолання труднощів при виникненні великої кількості ситуацій, що пов'язані 3 виконанням справ і прийняттям рішень в державному управлінні.

Висновки. Теоретичний аналіз і узагальнення сучасних підходів вивчення проблеми відкладання важливих справ i прийняття рішень показали, що феномен прокрастинації є негативне явище, яке перешкоджає суспільному розвитку і розуміється як постійне відкладання важливих справ та прийняття рішень, що завжди повторюються всупереч усвідомленню державними службовцями негативних наслідків та неготовністю взяти на себе відповідальність.

За умови неадаптивних копінг-стратегій поведінки, державні службовці використовують тактику прокрастинації та сфера пошуку рішення 3 подолання неприємної ситуації обмежується діями, які зменшують його контакти 3 цим положенням, а дії 3 переборення неприємного стану активно скасовуються державними службовцями, як несприятливі.

Неадаптивні копінг-стратегії поведінки державних службовців є: спрямованість уваги на емоції; незгода; віддаленість; уникнення; ігнорування; примирення;дисимуляція. 
Отже, неадаптивні копінг-стратегії поведінки у подоланні складних ситуацій при виконанні справ і прийняття рішень є предикторами прокрастинації державних службовців в управлінській діяльності та характеризуються: нездатністю до планування своїх дій, невмінням правильно оцінити ситуацію, пасивність дій спрямованих на припинення неприємного стану.

\section{Стаття надійшла до редакції: 14.06 .20}

\section{INAPPROPRIATE COPING STRATEGIES OF BEHAVIOR AS PREDICTORS OF PROCRASTINATION OF CIVIL SERVANTS}

Lyudmila Kotliar, Associate Professor, doctoral student of the department public administration and public service of the National Academy for Public Administration under the President of Ukraine, Kyiv, Ukraine

The article is devoted to the study of maladaptive coping strategies of behavior as predictors of procrastination of civil servants, to identify the main trends. A civil servant, as a subject of management, in the performance of his / her professional functions, constantly works in the conditions of decision-making to overcome the negative impact of difficult situations, such that their parameters exceed his / her competencies and resource potential. The professionalism of civil servants is manifested in the ability to overcome difficulties in the face of a large number of situations related to decision-making, which should not be postponed.

If the coping strategy is not adaptive, the civil servant uses procrastination tactics and the scope for finding a solution to the unpleasant situation is limited to actions that reduce his contact with this situation, and actions to overcome the unpleasant situation are actively canceled by the civil servant as unfavorable.

Inappropriate coping strategies of behavior in overcoming difficult situations in the performance of cases and decision-making 
are predictors of procrastination of civil servants in management. The analysis of scientific sources identifies the essence and main features of maladaptive coping strategies of behavior, which are a means of predicting the procrastination of civil servants in management. In particular, the scientific article analyzes the current scientific approaches to the definition of terms. Identified the most important aspects of the above phenomena have shown that procrastination is a negative phenomenon that hinders social development and is understood as the constant postponement of topical and important cases and decisions that are always repeated despite the awareness of civil servants of negative consequences and unwillingness to take responsibility.

The author's attitude to the definition of maladaptive coping strategies of behavior in overcoming difficult situations in the performance of cases and decision-making, which are predictors of procrastination of civil servants in management, is represented. Non-adaptive coping strategies of behavior are: focusing on emotions and their solution; denial; mental and behavioral alienation; avoidance; disregard; reconciliation; dissimulation.

Key words: civil servant, procrastination, political procrastination, predictor, coping strategies of behavior, non-adaptive coping strategies of behavior.

\section{Received: 14.06.20}

\section{References}

1. Abytov, Y.R. (2013). Osobennosty sovladanyia so stressom v norme y pry psykhosomatycheskykh y nevrotycheskykh rasstroistvakh [Features of coping with stress in health and psychosomatic and neurotic disorders]. Psykholohycheskyi zhurnal - Psychological journal, 34, 1, 8696 [in Russian].

2. Bazyka, Ye.L. (2012). Fenomen psykhofiziolohichnoho stanu prokrastynatsii [The phenomenon of psychophysiological state of procrastination]. Mezhdystsyplynarnie yssledovanyia v nauke y obrazovanyy - 
Interdisciplinary research in science and education, 1 Kyiv. Retrieved from www.es.rae.ru/mino/158-1023 [in Ukrainian].

3. Varvarycheva, Ya.Y. (2010). Fenomen prokrastynatsyy: problemi y perspektyvi yssledovanyia [The phenomenon of procrastination: problems and prospects of the study]. Voprosi psykholohyy - Questions of psychology, 3, 12113 [in Russian].

4. Vasylenko, M.M., Maksymenko, S.D. (2009). Suchasni napriamy psykholohichnykh doslidzhen kopinh-stratehii [Modern directions of psychological research of coping strategies]. Problemy zahalnoi ta pedahohichnoi psykholohii: zb. nauk. pr. Instytutu psykholohii im. H.S. Kostiuka APN Ukrainy - Problems of general and pedagogical psychology: collection. Science. etc. Institute of Psychology. G.S. Kostyuk Academy of Pedagogical Sciences of Ukraine, 11, 7, 95-107 [in Ukrainian].

5. Vorobieva, V.V. \& Yakymanskaia, Y.S. (2003). Psykholohyia leny: postanovka problemi [The Psychology of Laziness: Problem Statement]. Orenburh [in Russian].

6. Dvornyk, M.S. (2014). Sotsialno-psykholohichni praktyky vidterminuvannia v konstruiuvanni osobystistiu vlasnoho maibutnoho: dys. kand. psykhol. nauk: 19.00.05 [Socio-psychological practices of deferment in the construction of a person's own future: dis. cand. psychol. science: 19.00.05]. Kyiv [in Ukrainian].

7. Didukh, M.M. (2014). Stan rozvytku komponentiv konstruktyvnoi kopinh-povedinky u pratsivnykiv orhaniv vnutrishnikh sprav [The state of development of components of constructive coping behavior in law enforcement officers]. Problemy zahalnoi ta pedahohichnoi psykholohii: zb. nauk. pr. Instytutu psykholohii im. H.S. Kostiuka APN Ukrainy - Problems of general and pedagogical psychology: collection. Science. etc. Institute of Psychology. G.S. Kostyuk Academy of Pedagogical Sciences of Ukraine, Vyp. 26, 129-143 [in Ukrainian].

8. Ylyn, E.P. (2011). Rabota y lychnost. Trudoholyzm, perfektsyonyzm, len' [Work and personality. Workaholism, perfectionism, laziness]. Moskva: Pyter [in Russian].

9. Kovilyn, V.S. (2013). Teoretycheskye osnovi yzuchenyia fenomena prokrastynatsyy [Theoretical foundations of the study of the phenomenon of procrastination]. Elektronnii nauchnyi zhurnal «Lychnost v meniaiushchemsia 
myre: zdorovie, adaptatsyia, razvytye» - Electronic scientific journal «Personality in a changing world: health, adaptation, development», 2. Retrieved from http:// www.hunjournal.rzgmu.ru [in Russian].

10. Mendelevych, V.D. (1996). Antytsypatsyonnie mekhanyzmi nevrozoheneza [Anticipatory mechanisms of neurosogenesis]. Psykholohycheskyi zhurnal - Psychological journal, 4, 107-115 [in Russian].

11. Motruk, T.O. \& Stetsenko, D. V. (2014). Prokrastynatsiia yak inhibitor rozvytku uspishnoi osobystosti [Procrastination yak ingibitor development of successful specialties]. Aktualni pytannia suchasnoi psykholohii: materialy I Vseukrainskoi naukovo-praktychnoi konferentsii studentiv, aspirantiv i molodykh vchenykh - Relevant nutrition of current psychology: materials of the 1st All-Ukrainian scientific-practical conference of students, graduate students and young students. Sumy : Vyd-vo SumDPU imeni A. S. Makarenka [in Ukrainian].

12. Michko, V.N. (2016). Prokrastynatsyia kak fenomen y obraz zhyzny sovremennoho cheloveka [Procrastination as a phenomenon and way of life of a modern person]. Molodoi uchenyi - Young scientist, 25, 651-654. Retrieved from https://moluch.ru/archive/ 129/35866/

13. Nasynovska, O.Ie. \& Yakubovska, M.Ia. (1984). Psykholohichnyi barier yak zakhysnyi mekhanizm osoby $\mathrm{v}$ konfliktnii sytuatsii [Psychological barrier as a protective mechanism of a person in a conflict situation]. Moskva: Znannia [in Ukrainian].

14. Petrovskoho, A.V. \& Yaroshevskoho, M.H. (1990). Psykholohiia Slovnyk [Psychology. Dictionary]. Moskva: «Politvydav» [in Ukrainian].

15. Kharakterystyka zashchytno-sovladaiushcheho stylia povedenyia vrachei-psykhyatrov y vrachei khyrurhycheskykh spetsyalnostei [Characteristics of the defensive-coping style of behavior of psychiatrists and doctors of surgical specialties]. Aktualnie problemy klynycheskoi psykholohyy y psykhofyzyolohyy - Actual problems of clinical psychology and psychophysiology, 11-15 [in Ukrainian].

16. Shaihorodskyi, Yu.Zh. (2014). Fenomen politychnoi prokrastynatsii yak vyklyk stratehichnomu myslenniu [The Phenomenon of Political Procrastination as a Victory to the Strategic Mission]. Naukovyi chasopys NPU imeni M.P. Drahomanova. Politychni nauky ta metodyka vykladannia sotsialno-politychnykh dystsyplin - Scientific hour writing of NPU imeni 
M.P. Dragomanova. Political science and methodology of social and political disciplines, 22, 85-91 [in Ukrainian].

17. Shaihorodskyi, Yu.Zh. (2013). Syndrom politychnoi prokrastynatsii: prychyny i naslidky [Political procrastination syndrome: causes and consequences]. Politychnyi menedzhment: nauk. zhurnal - Political Management: science magazine, 59, 16-29 [in Ukrainian].

18. Amirkhan, J. H. (1990). Factor analiticaly drived measure of coping: the strategy indicator. J. of Personality and Social Psychology, 59, 1066-1074 [in English].

19. Equainville, D. (2016). Encyclopédie joyeuse de la procrastination. Paris: Le Contrepoint [in French].

20. Lay, C.H. (1986). At last, my research article on procrastination. Journal of Research in Personality, 20 (4), 474-495 [in English].

21. Lazarus, R. \& Folkman, S. (1984). Stress appraisal and coping. N.Y.: Springer, 22-46 [in English].

\section{Відомості про авторів / Information about the Authors}

Котляр Людмила Іванівна: Національна академія державного управління при Президентові України, вул. Антона Цедіка, 20 м. Київ, 03057, Україна.

Lyudmila Kotlyar: National Academy for Public Administration under the President of Ukraine, 20, Anton Tsedyk St., Kyiv, 03057, Ukraine.

ORCID. ORG./0000-0002-4785-0956

\section{E-mail: kotliar.62@ukr.net}

